\title{
IMPROVING STUDENTS' LEARNING OUTCOMES IN THE THEME OF "PERISTIWA DALAM KEHIDUPAN" THROUGH VIDEO - ASSISTED STUDENT TEAMS ACHIEVEMENT DIVISION (STAD) MODEL AT GRADE V ELEMENTARY SCHOOL
}

\author{
Fahriza Deaz Ismaya ${ }^{1}$, Murtono $^{2}$, Deka Setiawan $^{3}$ \\ ${ }^{1,2,3}$ PGSD, Universitas Muria Kudus, Kudus, Indonesia \\ 1201633212@std.umk.ac.id, 2murtono@umk.ac.id,3 deka.setiawan@umk.ac.id
}
PENINGKATAN HASIL BELAJAR TEMA PERISTIWA DALAM KEHIDUPAN MENGGUNAKAN MODEL STUDENT TEAMS ACHIEVEMENT DIVISION BERBANTUAN VIDEO SISWA KELAS V SEKOLAH DASAR

\begin{tabular}{|c|c|}
\hline ARTICLE HISTORY & $\overline{\text { ABSTRACT }}$ \\
\hline $\begin{array}{l}\text { Submitted: } \\
\text { 07 Agustus } 2020 \\
07^{\text {th }} \text { August } 2020\end{array}$ & $\begin{array}{l}\text { Abstract: This study aimed to describe the application of student team achievement division } \\
\text { (STAD) model assisted by instructional video media to improve students' learning } \\
\text { outcomes.This study utilized classroom action research (CAR) consisting of two cycles. Each } \\
\text { cycle consisted of four stages namely planning, implementating actions, observing, and } \\
\text { reflecting. The subjects of this study were } 21 \text { fifth grade students at SD } 5 \text { Gondoharum, } \\
\text { Kecamatan Jekulo, Kabupaten Kudus. There were } 13 \text { male students and } 8 \text { female students in } \\
\text { this study. Data were collected through observations, interviews, tests, and documentations. } \\
\text { The results of observations revealed that the teacher's skills in managing learning increased by } \\
\text { a percentage of } 76 \% \text { (Good) in cycle I to } 87 \% \text { (Very Good) in cycle II. Meanwhile, students } \\
\text { learning outcomes in pre-cycle aspects of IPS content reached the completeness for } 47.6 \% \\
\text { (need guidance). It increased in cycle I to } 71.4 \% \text { (good) and in cycle II to } 85.7 \% \text { (good). } \\
\text { Moreover, the learning outcomes in pre-cycle knowledge aspects of Bahasa Indonesia content } \\
\text { reached the completeness for } 42.9 \% \text { (need guidance). Then, it increased in cycle I to 66.7\% } \\
\text { (need guidance) and in cycle } 2 \text { to } 90.5 \% \text { (very good). Finally, the students' learning outcomes } \\
\text { in the skills aspects in cycle I reached the average of 76.2\% (enough) and increased in cycle II } \\
\text { to } 85.7 \% \text { (good). }\end{array}$ \\
\hline
\end{tabular}

Accepted:

14 Juni 2021

$14^{\text {th }}$ June 2021

Published:

26 Juni 2021

$26^{\text {th }}$ June 2021
Keywords: student teams achievement division model, video media, learning outcomes

\begin{abstract}
Abstrak: Penelitian ini bertujuan mendeskripsikan penerapan model student teams achievement division (STAD) berbantuan media video pembelajaran untuk meningkatkan hasil belajar siswa. Penelitian ini menggunakan penelitian tindakan kelas (PTK) terdiri atas 2 siklus. Pada setiap siklus terdapat 4 tahapan yaitu perencanaan, pelaksanaan tindakan, pengamatan dan refleksi. Subjek dalam penelitian ini adalah siswa kelas V SD 5 Gondoharum, Kecamatan Jekulo, Kabupaten Kudus. Siswa kelas V berjumlah 21 siswa yaitu 13 siswa lakilaki dan 8 siswa perempuan. Teknik pengumpulan data meliputi observasi, wawancara, tes, dan dokumentasi. Hasil observasi keterampilan guru dalam mengelola pembelajaran mengalami peningkatan persentase 76\% (Baik) pada siklus I menjadi 87\% (Sangat Baik) pada siklus II. Hasil belajar siswa aspek pengetahuan prasiklus muatan IPS ketuntasannya mencapai 47,6\% (Perlu Bimbingan), siklus I menjadi 71,4\% (Baik), dan meningkat pada siklus II mencapai $85,7 \%$ (Baik). Hasil belajar aspek pengetahuan prasiklus muatan bahasa Indonesia ketuntasannya mencapai 42,9\% (Perlu Bimbingan), siklus I mencapai 66,7\% (Perlu Bimbingan), dan siklus II mencapai 90,5\% (Sangat Baik). Hasil belajar siswa aspek keterampilan pada siklus I rata-rata persentasenya mencapai 76,2\% (Cukup) dan meningkat pada siklus II mencapai 85,7\% (Baik).
\end{abstract}

Kata Kunci: model student teams achievement division, video media, hasil belajar

\section{CITATION}

Ismaya, F. D., Murtono, M., \& Setiawan, D. (2021). Improving Students' Learning Outcomes in the Theme of "Peristiwa Dalam Kehidupan" through Video - Assisted Student Teams Achievement Division (STAD) Model at Grade V Elementary School. Primary: Jurnal Pendidikan Guru Sekolah Dasar, 10 (3), 604-617. DOI: http://dx.doi.org/10.33578/jpfkip.v10i3.7998. 


\section{PENDAHULUAN}

Teknologi di era digital saat ini berkembang sangat pesat. Penggunaan teknologi dibutuhkan manusia untuk membantu menyelesaikan berbagai pekerjaan, misalnya saja bidang pendidikan. Teknologi di bidang pendidikan diharapkan mampu membantu guru dan siswa dalam proses belajar mengajar. Pendidikan bertujuan untuk meningkatkan sumber daya manusia (SDM) yang berkualitas, handal dan terpercaya. Pendidikan adaah segala pengalaman belajar yang berlangsung dalam segala situasi hidup yang mempengaruhi pertumbuhan individu (Mudyahardjo, 2010: 3). Berdasarkan pengertian tersebut dapat dijelaskan bahwa pendidikan terjadi di lingkungan sekitar dan berlangsung sepanjang hidup dan segala situasi.

Pendidikan di Indonesia sudah mengalami beberapa kali penggantian kurikulum. Kurikulum 2013 merupakan kurikulum yang diterapkan pemerintah mulai tahun 2013 sampai sekarang. Muhammad Nuh (dalam Kurinasih dan Sani, 2014: 21-22) mengemukakan bahwa kurikulum 2013 bersifat tematik terintegratif yang pokok bahasannya berdasarkan tema dengan menggabungkan beberapa muatan pelajaran. Kurikulum 2013 menekankan pada 3 aspek yaitu aspek sikap, keterampilan dan pengetahuan. Hal ini sejalan dengan pendapat Susanto (2013: 5) bahwa hasil belajar adalah perubahan-perubahan yang terjadi pada diri siswa, baik yang menyangkut aspek kognitif, afektif dan psikomotorik.

Berdasarkan hasil observasi dan wawancara pada 2 siswa dan guru kelas V SD 5 Gondoharum tanggal 10 Oktober 2019 muncul permasalahan-permasalahan. Guru kurang menggunakan metode, model dan media yang bervariasi. Ceramah adalah metode yang sering digunakan sehingga pembelajaran masih berpusat pada guru dan mengakibatkan siswa lebih suka mengobrol dengan teman satu kelas diluar materi pelajaran. Pemahaman siswa tentang materi sejarah atau hafalan masih kurang dan keterampilan siswa dalam mengemukakan pendapat masih kurang.

Hasil observasi dan wawancara sejalan dengan hasil nilai penilaian tengah semester (PTS) muatan IPS dan bahasa Indonesia kelas V SD 5 Gondoharum tahun ajaran 2019/2020 masih kurang dari indikator keberhasilan. Niai PTS menjadi acuan nilai prasiklus dalam penelitian ini. Nilai Kriteria ketuntasan minimal (KKM) muatan IPS dan bahasa Indonesia adalah 70. Pada muatan IPS siswa yang tuntas adalah 10 dengan persentase ketuntasan klasikal mencapai 47.6\%; sedangkan pada muatan bahasa Indonesia siswa yang tuntas 9 dengan persentase mencapai $42.9 \%$.

Salah satu upaya yang dilakukan untuk meningkatkan hasil belajar yaitu dengan menggunakan model pembelajaran student teams achievement division (STAD). Model STAD merupakan model kooperatif paling sederhana. Gagasan utama dibalik model STAD adalah untuk memotivasi para siswa untuk mendorong dan membantu satu sama lain untuk menguasai keterampilanketerampilan yang disajikan oleh guru (Hamdayama, 2014: 117). Tahapan-tahapan model STAD terdiri dari presentasi kelas, kerja kelompok, kuis, peningkatan nilai individu, dan penghargaan kelompok (Shoimin, 2014: 186-187). Alasan menggunakan model STAD adalah siswa mampu aktif mengikuti pembelajaran dengan penerapan tutor sebaya dan saling bekerja sama dalam meraih penghargaan kelompok. Sesuai dengan pendapat Aji dan Julianto (2019) dalam penelitian tindakan kelas (PTK) dengan judul "Penerapan Model Pembelajaran STAD untuk meningkatkan hasil belajar IPA siswa kelas IV tema Cita-citaku SDN 02 Tulungrejo Banyuwangi" mengalami peningkatan. Pada siklus I didapat ketuntasan klasikal sebesar 67.5\% dengan rata-rata 72.97; sedangkan pada siklus II ketuntasan klasikalnya mencapai $82.7 \%$ dengan rata-rata 81.08 . Peningkatan pada keterampilan guru pada siklus I rata- 
ratanya sebesar $76.45 \%$ dan meningkat pada siklus II menjadi $86.9 \%$.

Media pembelajaran menjadi sarana penunjang untuk mempermudah jalannya penyampaian materi. Penggunaan media video memadukan antara mendengar dan melihat sehingga sesuai jika digunakan pada materi pemahaman sejarah dan keterampilan berbicara. Video merupakan bahan pembelajaran tampak dengar (audio visual) yang dapat digunakan untuk menyampaikan pesan-pesan/materi pelajaran (Rusman, 2012: 15). Video pembelajaran dibuat dengan media powtoon. Powtoon merupakan web apps online untuk membuat prsentasi atua video animasi kartun dengan cara yang mudah (Mahendra, 2016: 71). Pemilihan powtoon sebagai media menampilkan animasi kartun sehingga penyampaian materi lebih tersampaikan dan memotivasi siswa untuk mengikuti pembelajaran.

Tema Peristiwa dalam Kehidupan dengan menerapkan model STAD berbantuan media video pembelajaran dirasa cocok dengan materi IPS tentang sejarah sebelum kemerdekaan Indonesia melawan penjajah dan saat proklamasi kemerdekaan. Selain itu, dengan model dan media tersebut dinilai cocok dalam meningkatkan keterampilan berbicara. Dengan penerapan STAD siswa mampu menggali pengetahuan siswa melalui tutor sebaya dan saling bekerja sama untuk mendapatkan penghargaan kelompok dalam tahapan kuis.

Berdasarkan latar belakang tersebut, rumusan masalah dalam penelitian ini adalah (1) bagaimana peningkatan keterampilan guru dalam mengelola pembelajaran melalui model student teams achievement division (STAD) berbantuan media video pembelajaran tema 7 "Peristiwa dalam Kehidupan" pada muatan IPS dan bahasa Indonesia kelas V SD 5 Gondoharum Kudus? (2) bagaimana peningkatan hasil belajar siswa melalui model student teams achievement division (STAD) berbantuan media video pembelajaran tema 7 "Peristiwa dalam Kehidupan" pada muatan IPS dan bahasa Indonesia kelas $\mathrm{V}$ SD 5 Gondoharum Kudus?

Adapun tujuan dari penelitian ini sebagai berikut. (1) Mendeskripsikan peningkatan keterampilan guru dalam mengelola pembelajaran melaui model student teams achievement division (STAD) berbantuan media video pembelajaran tema 7 "Peristiwa dalam Kehidupan" pada muatan IPS dan bahasa Indonesia kelas $\mathrm{V}$ SD 5 Gondoharum Kudus dan (2) Mendiskripsikan peningkatan hasil belajar siswa melalui model student teams achievement division (STAD) berbantuan media video pembelajaran tema 7 "Peristiwa dalam Kehidupan" pada muatan IPS dan bahasa Indonesia kelas V SD 5 Gondoharum Kudus.

\section{KAJIAN TEORI}

Kajian teori pada artikel ini akan membahas tentang keterampilan guru dalam mengelola pembelajaran, hasil belajar, model student teams achievement division (STAD), video pembelajaran, muatan pelajaran IPS dan muatan pelajaran bahasa Indonesia. Keterampilan guru dalam mengelola pembelajaran adalah kemampuan yang dimiliki guru yang dapat diterapkan dan dipelajari guru. Keterampilan guru dalam mengelola pembelajaran sesuai yang dikemukakan oleh Rusman (Ardianti, Ulya dan Ismaya, 2018: 153-154) yaitu keterampilan membuka pelajaran, keterampilan bertanya, keterampilan memberi penguatan, keterampilan mengadakan variasi, keterampilan menjelaskan, keterampilan membimbing diskusi kelompok kecil, keterampilan mengelola kelas, keterampilan pembelajaran perseorangan, dan keterampilan menutup pembelajaran.

Hasil belajar adalah kompetensi atau kemampuan tertentu baik kognitif, afektif maupun psikomotorik yang dicapai atau dikuasai peserta didik setelah mengikuti proses belajar mengajar (Kunandar, 2013:12). Hasil belajar dalam penelitian ini fokus pada hasil belajar aspek pengetahuan dan keterampilan. 
Aspek pengetahuan adalah ranah yang membahas tujuan pembelajaran berkenaan dengan proses mental yang berawal dari tingkat pengetahuan rendah sampai ke tingkat yang lebih tinggi (Uno dkk, 2014: 5). Sudjana (2011: 55) mengemukakan hasil belajar aspek keterampilan tampak dalam bentuk keterampilan (skill), kemampuan bertindak individu (seseorang). Dalam penelitian ini hasil belajar aspek keterampilan terfokus pada keterampilan berbicara siswa. Berbicara adalah kemampuan mengucapkan bunyi-bunyi artikulasi atau kata-kata untuk mengekspresikan, menyatakan atau menyampaikan pikiran, gagasan dan perasaan (Tarigan, 2008: 16).

Model STAD mengacu kepada belajar kelompok siswa, menyajikan informasi akademik baru kepada siswa setiap minggu menggunakan persentasi verbal atau teks (Shoimin, 2014: 185). Dalam penelitian ini menggunakan tahapan-tahapan model STAD sesuai pendapat Shoimin $(2014,186-187)$ bahwa tahapan model STAD terdiri dari persentasi kelas (class presentation), kerja kelompok (team works), kuis (quizzes), peningkatan nilai individu (individual improvement score), dan penghargaan kelompok (team recognition).

Media video pembelajaran digunakan untuk mendukung proses belajar mengajar. Video merupakan bahan pembelajaran tampak dengan (audio visual) yang dapat digunakan untuk menyampaikan pesan-pesan/materi pelajaran (Rusman, 2012: 15). Pemilihan media video pembelajaran karen terdapat kelebihan-kelebihan yang dimiliki media video pembelajaran jika digunakan dalam pembelajaran. Media video pembelajaran memiliki kelebihan yaitu video menambah suatu dimensi baru di dalam pembelajaran, video menyajikan gambar bergerak kepada siswa disamping suara yang menyertainya dan video dapat menampilkan suatu fenomena yang sulit untuk dilihat secara nyata (Daryanto, 2012: 79).
Ilmu pengetahuan sosial (IPS) merupakan salah satu muatan pelajaran di sekolah dasar(SD). Untuk jenjang SD/MI, pengorganisasian materi mata pelajaran IPS menganut pendekatan terpadu (integrated), artinya materi pelajaran dikembangkan dan disusun tidak mengacu pada aspek kehidupan nyata (factual/real) peserta didik sesuai dengan karakteristik usia, tingkat perkembngan berpikir, dan kebiasaan bersikap dan berperilakunya (Sapriya, 2009:194). Mata pelajaran bahasa Indonesia SD adalah program untuk mengembankan pengetahuan, keterampilan berbahasa dan sikap positif terhadap bahasa Indonesia (Santoso dkk, 2009: 36).

\section{METODE PENELITIAN}

Penelitian ini menggunkan metode penelitian tindakan kelas (PTK). Mulyasa (2013: 10) mengemukakan bahwa PTK sebagai penelitian tindakan (action research) yang dilakukan dengan tujuan untuk memperbaiki kualitas proses dan hasil belajar sekelompok peserta didik. Hakikat penelitian tindakan kelas (PTK) merupakan ragam penelitian pembelajaran yang berkonteks kelas yang dilaksanakan oleh guru untuk memecahkan masalah-masalah pembelajaran yang dihadapi oleh guru, memperbaiki mutu dan hasil pembelajaran (Sumadoyo, 2013: 10). Jenis penelitian ini dipilih berdasarkan hasil observasi dan wawancara yang menunjukkan bahwa masih terdapat kesulitan-kesulitan yang dihadapi guru dan siswa. Subjek dalam penelitian yaitu pada siswa kelas V SD 5 Gondoharum tahun ajaran 2019/2020. Siswa kelas V berjumlah 21 siswa meliputi 13 siswa laki-laki dan 8 siswa perempuan.

Pada penelitian ini bertujuan memperbaiki permasalahan-permasalahan yang dihadapi pada kelas V SD 5 Gondoharum yaitu tentang hasil belajar siswa. Penelitian tindakan kelas ini ada 4 tahapan yaitu perencanaan, pelaksanaan tindakan, observasi dan refleksi (Arikunto dkk, 2011: 16). Dalam penelitian ini melaksanakan 2 siklus yang 
setiap siklusnya terdiri atas 2 pertemuan. Tahap pertama adalah tahap perencanaan, yaitu tahap mempersiapkan instrumen penelitian berupa perangkat pembelajaran yang dipergunakan. Tahap kedua adalah tahap pelaksanaan tindakan, yaitu penerapan pelaksanaan pembelajaran sesuai RPP yang sudah dibuat. Tahap ketiga adalah tahap pengamatan yaitu peneliti mengamati hasil observasi keterampilan guru dalam mengelola pembelajaran dan observasi hasil belajar siswa aspek keterampilan. Tahap pengamatan dibantu guru kelas $\mathrm{V}$ dan teman sejawat. Tahap terakhir adalah tahap refleksi, yaitu bahan pertimbangan dalam menentukan langkah selanjutnya.

Salah satu kegiatan penting dalam PTK adalah pengumpulan data. Teknik pengumpulan data berupa tes, wawancara, observasi dan dokumentasi. Instrumen penelitian lembar wawancara yang disesuaikan sesuai indikator yang dibuat. Tes dilakukan untuk mengetahui hasil bealajar siswa aspek pengetahuan dilaksanakan pada akhir setiap siklus baik siklus I maupun siklus II. Soal evaluasi berupa 10 butir soal uraian. Lembar observasi hasil belajar aspek keterampilan berbentuk pengisian skor pada setiap indikator atau aspek yang diamati dengan skor minimalnya adalah 1 dan skor maksimalnya adalah 4. Lembar observasi keterampilan guru dalam mengelola pembelajaran berupa pengisisan tanda checklist $(\sqrt{ })$.

Dalam penelitian ini, persentase ketuntasan hasil belajar siswa aspek pengetahuan dan keterampilan dapat diklasifikasikan sesuai Tabel 1.

Tabel 1. Kriteria Penilaian Hasil Belajar Siswa Aspek Pengetahuan dan Keterampilan

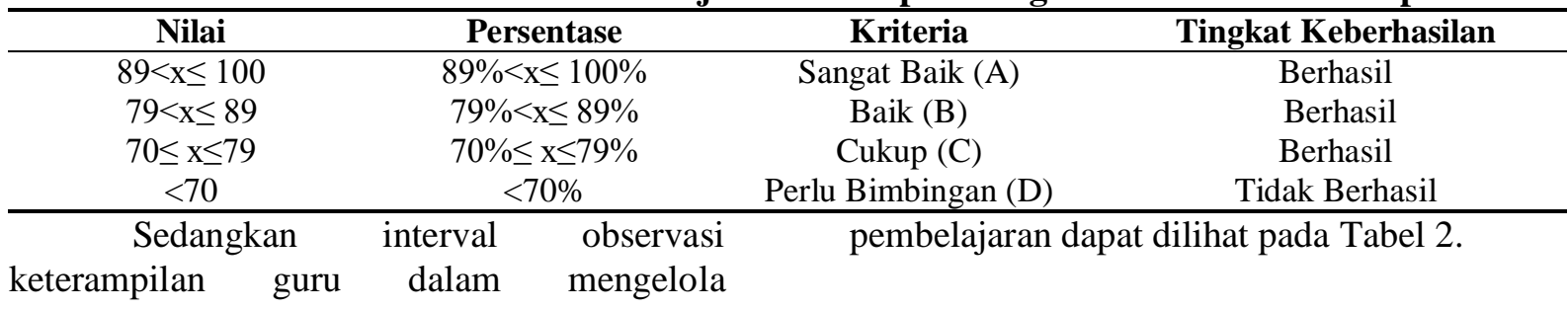

Tabel 2. Observasi Keterampilan Guru dalam Mengelola Pembelajaran

\begin{tabular}{cccc}
\hline Nilai & Persentase & Kriteria & Tingkat Keberhasilan \\
\hline $82-100$ & $82 \%-100 \%$ & Sangat Baik (SB) & Berhasil \\
$63-81$ & $63 \%-81 \%$ & Baik (B) & Berhasil \\
$44-62$ & $44 \%-62 \%$ & Cukup (C) & Tidak Berhasil \\
$25-43$ & $25 \%-43 \%$ & Kurang (K) & Tidak Berhasil \\
\hline
\end{tabular}

\section{HASIL DAN PEMBAHASAN Hasil}

1. Keterampilan guru dalam mengelola pembelajaran

Hasil observasi keterampilan guru dalam mengelola pembelajaran pada siklus I memperoleh persentase $73 \%$ dengan kriteria baik pada pertemuan 1, sedangkan pada pertemuan 2 mengalami peningkatan menjadi $79 \%$ dengan kriteria baik. Berdasarkan kedua pertemuan pada siklus I, maka persentase hasil observasi keterampilan guru dalam mengelola pembelajaran pada siklus I $76 \%$ dengan kriteria baik.

Hasil observasi keterampilan guru dalam mengelola pembelajaran pada siklus II memperoleh persentase $84 \%$ dengan kriteria sangat baik pada pertemuan 1, sedangkan pada pertemuan 2 mengalami peningkatan menjadi 90\% dengan kriteria sangat baik. Berdasarkan kedua pertemuan siklus II, maka persentase hasil observasi keterampilan guru dalam mengelola pembelajaran pada siklus II $87 \%$ dengan kriteria sangat baik. 
Observasi keterampilan guru dalam mengelola pembelajaran pada siklus I dan siklus II menglami peningkatan. Adapun peningkatan observasi keterampilan guru dalam mengelola pembelajaran pada siklus I dan siklus II dapat dilihat pada Gambar 1.

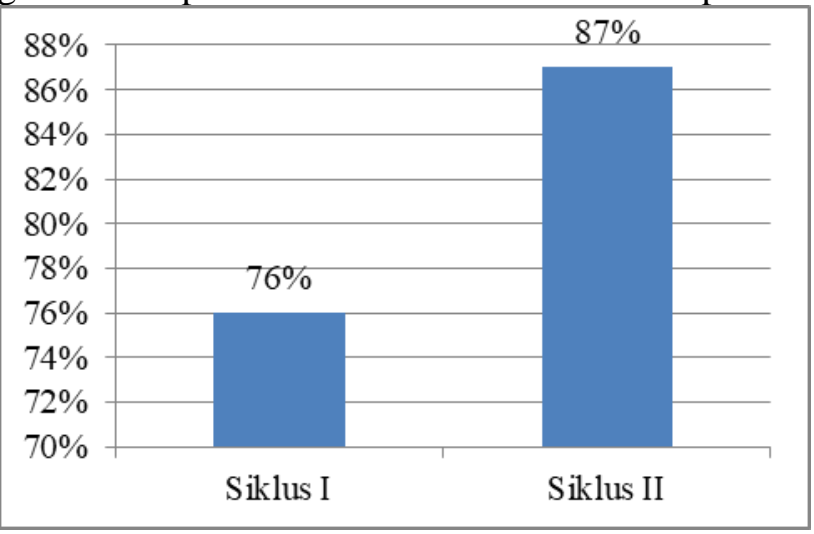

\section{Gambar 1. Diagram Persentase Hasil Observasi Keterampilan Guru dalam Mengelola Pembelajaran}

\section{Hasil Belajar Siswa}

Hasil belajar adalah perubahanperubahan yang terjadi pada diri siswa, baik yang menyangkut aspek kognitif, afektif dan psikomotorik (Susanto, 2013: 5). Hasil belajar siswa terfokus pada hasil belajar aspek pengetahuan dan aspek keterampilan. Hasil belajar siswa aspek pengetahuan pada muatan IPS dan bahasa Indonesia dengan menerapkan model student teams achievement division (STAD) berbatuan media video pembelajaran mengalami peningkatan. Hasil belajar siswa aspek pengetahuan diperoleh dari hasil tes evaluasi pada akhir siklus baik akhir siklus I dan akhir siklus II. Kriteria ketuntasan minimal (KKM) muatan IPS dan bahasa Indonesia adalah 70. Berikut ini uraian hasil belajar IPS aspek pengetahuan.

\section{Hasil Belajar IPS Aspek Pengetahuan}

Hasil belajar IPS aspek pengetahuan diperoleh dari prasiklus, siklus I dan siklus II. Hasil belajar aspek pengetahuan muatan IPS pada prasiklus dapat dilihat pada Gambar 2.

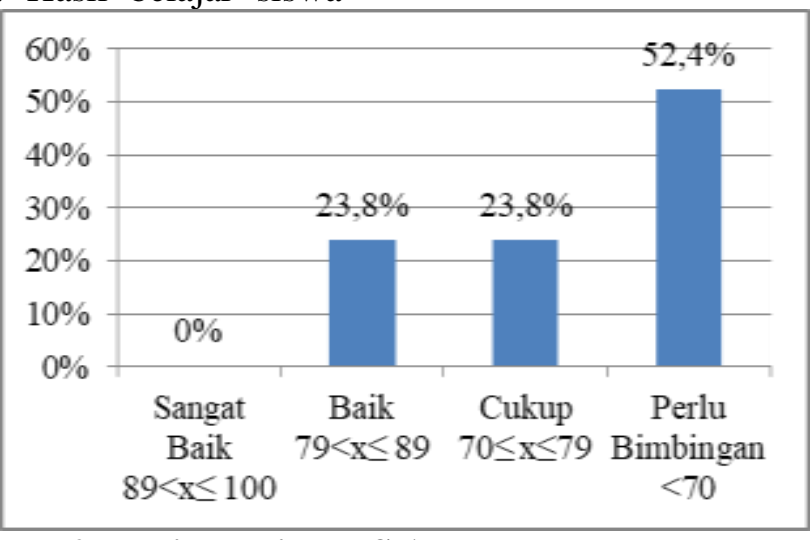

Gambar 2. Hasil Belajar IPS Aspek Pengetahuan Prasiklus

Berdasarkan Gambar 2 menunjukkan bahwa hasil belajar siswa aspek pengetahuan muatan IPS pada prasiklus masih kurang. Kriteria sangat baik belum ada siswa yang memperolehnya, kriteria baik diperoleh 5 siswa dengan persentase $23.8 \%$; kriteria cukup diperoleh 5 siswa dengan persentase mencapai 23.8\%; dan kriteria perlu bimbingan diperoleh 
ISSN : 2303-1514 | E-ISSN : 2598-5949

11 siswa dengan persentasenya mencapai

pengetahuan siklus I dapat dilihat pada 52.4\%. Ketuntasan hasil belajar IPS aspek Gambar 3.

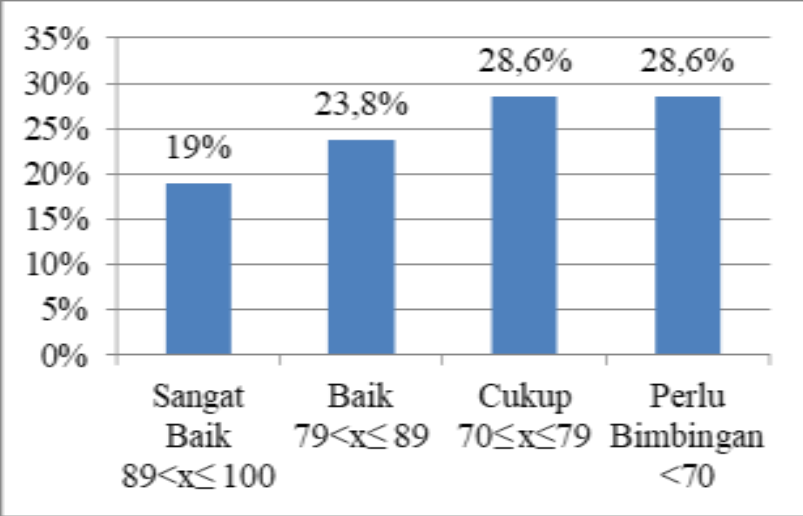

\section{Gambar 3. Hasil Belajar IPS Aspek Pengetahuan Siklus I}

Berdasarkan Gambar 3 menunjukkan bahwa hasil belajar siswa aspek pengetahuan siklus I pada mutan IPS masih rendah. Terdapat 4 siswa mendapat kriteria sangat baik dengan persentase mencapai $19 \%$, kriteria baik diperoleh 5 siswa dengan persentase mencapai $23.8 \%$ berkriteria baik, kriteria cukup diperoleh 6 siswa dengan persentase mencapai $28.6 \%$ berkriteria cukup, dan kriteria perlu bimbingan mencapai $28.6 \%$ yang artinya 6 siswa yang memperoleh kriteria tersebut. Berdasarkan hasil tersebut, perlu adanya penelitian lagi pada siklus II untuk meningkatkan hasil belajar siswa aspek pengetahuan muatan IPS pada siklus I. Ketuntasan hasil belajar IPS aspek pengetahuan siklus II dilihat pada Gambar 4.

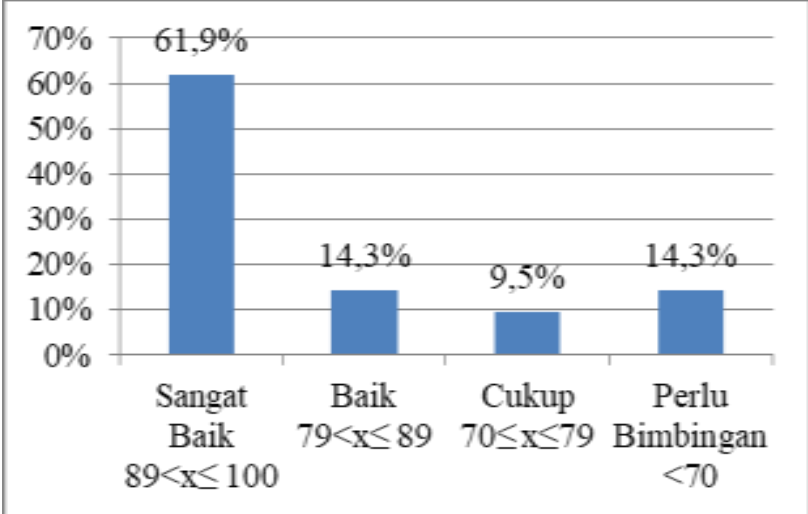

Gambar 4. Hasil Belajar IPS Aspek Pengetahuan Siklus II

Berdasarkan Gambar 4 menunjukkan hasil belajar siswa aspek pengetahuan siklus II pada muatan IPS mengalami peningkatan jika dibanding siklus I. Pada siklus II kriteria sangat baik diperoleh 13 siswa dengan persentasenya $61.9 \%$; kriteria baik diperoleh 3 siswa dengan persentasenya mencapai $14.3 \%$; kriteria cukup diperoleh 2 siswa dengan persentasenya mencapai $9.5 \%$; dan kriteria perlu bimbingan diperoleh 3 siswa dengan persentasenya mencapai $14.3 \%$.

Peningkatan ketuntasan hasil belajar siswa aspek pengetahuan muatan IPS pada prasiklus, siklus I dan siklus II dapat dilihat pada Gambar 5. 


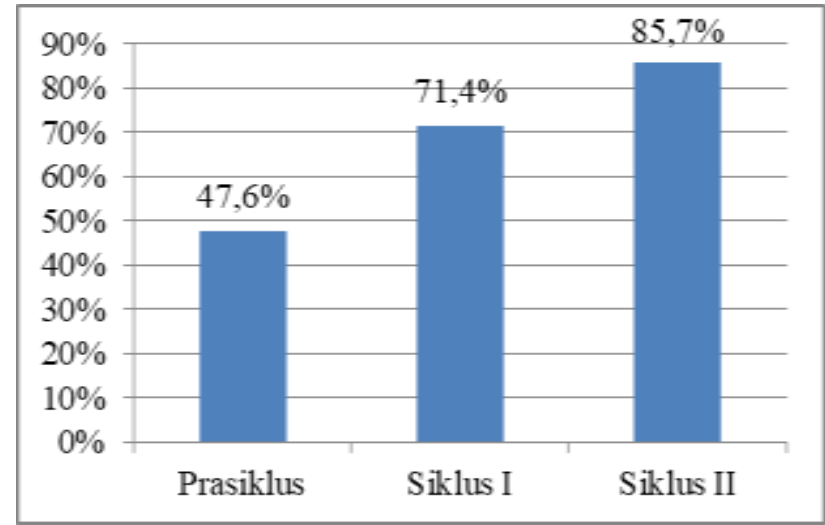

\section{Gambar 5. Diagram Ketuntasan Hasil Belajar Siswa Aspek Pengetahuan Muatan IPS}

Berdasarkan Gambar 5 menunjukkan bahwa hasil belajar siswa aspek pengetahuan muatan IPS mengalami peningkatan mulai dari prasiklus, siklus I dan siklus II. Hasil belajar siswa aspek pengetahuan muatan IPS dapat dikatakan berhasil jika persentase ketuntasan minimal $70 \%$. Pada prasiklus ketuntasan klasikalnya diperoleh 10 siswa dengan persentasenya mencapai $48 \%$ artinya berkriteria perlu bimbingan dan tergolong tidak berhasil. Siklus I ketuntasan klasikalnya diperoleh 15 siswa dengan persentasenya mencapai $71.4 \%$ artinya berkriteria cukup dan tergolong berhasil. Siklus II ketuntasan klasikalnya diperoleh 18 siswa dengan persentasenya mencapai $85.7 \%$ artinya berkriteria baik dan tergolong berhasil.

\section{Hasil Belajar Bahasa Indonesia Aspek} Pengetahuan

Hasil belajar aspek pengetahuan muatan bahasa Indonesia diperoleh dari prasiklus, siklus I dan siklus II. Hasil belajar aspek pengetahuan muatan bahasa Indonesia prasiklus dapat dilihat pada Gambar 6 .

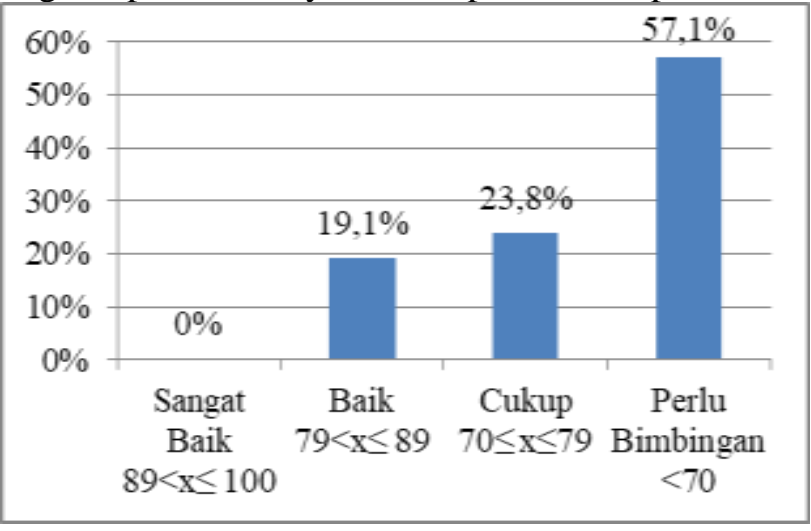

Gambar 6. Hasil Belajar Bahasa Indonesia Aspek Pengetahuan Prasiklus

Berdasarkang Gambar 6 menunjukkan bahwa tingkat ketuntasan siswa kurang dari indikator keberhasilan minimal $70 \%$ pada prasiklus. Pada prasiklus tidak ada siswa satupun yang memperoleh kriteria sangat baik, kriteria baik terdapat 4 siswa dengan ketuntasannya mencapai $19.1 \%$; kriteria cukup diperoleh 5 siswa dengan ketuntasannya mencapai $23.8 \%$; dan kriteria perlu bimbingan diperoleh 11 siswa dengan ketuntasannya mencapai $57.1 \%$. Ketuntasan hasil belajar 
aspek pengetahuan siklus I dapat dilihat pada Gambar 7.

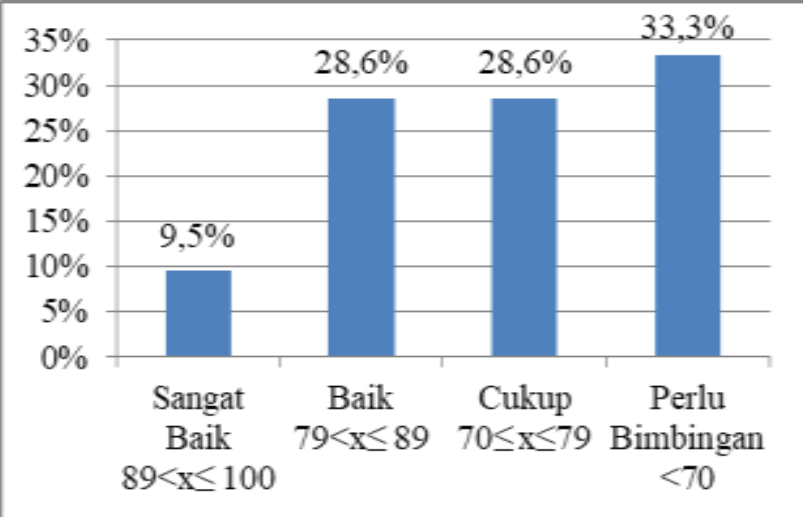

\section{Gambar 7. Hasil Belajar Bahasa Indonesia Aspek Pengetahuan Siklus I}

Berdasarkan Gambar 7 menunjukkan bahwa tingkat ketuntasan hasil belajar aspek pengetahuan siklus I mengalami peningkatan dibandingkan dengan prasiklus. Terdapat 2 siswa yang memperoleh kriteria sangat baik dengan persentasenya $9.5 \%$; terdapat 6 siswa dengan persentase mencapai $28.6 \%$ berkriteria baik, terdapat 6 siswa yang persentasenya mencapai $28.6 \%$ dengan kriteria cukup, dan kriteria perlu bimbingan terdapat 7 siswa dengan persentasenya mencapai $33.3 \%$. Ketuntasan hasil belajar aspek pengetahuan muatan bahasa Indonesia siklus II dapat pada Gambar 8.

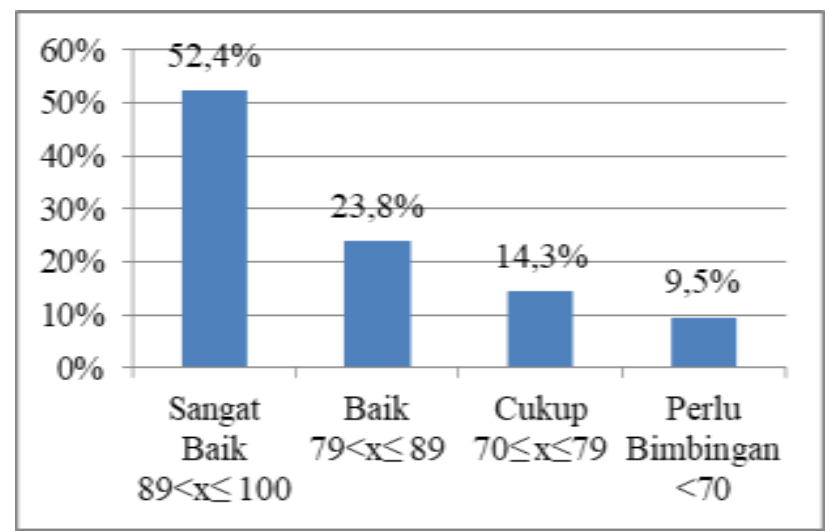

Gambar 8. Hasil Belajar Bahasa Indonesia Aspek Pengetahuan Siklus II

Berdasarkan Gambar 8 menunjukkan bahwa tingkat ketuntasan siswa mengalami peningkatan dari siklus I ke siklus II. Kriteria sangat baik diperoleh 11 siswa dengan persentasenya $52.4 \%$; kriteria baik diperoleh 5 siswa dengan persentasenya mencapai $23.8 \%$; kriteria cukup diperoleh 3 siswa dengan persentasenya $9.5 \%$; dan kriteria perlu bimbingan diperoleh 2 siswa dengan persentasenya mencapai $9.5 \%$. Peningkatan ketuntasan hasil belajar siswa aspek pengetahuan muatan bahasa Indonesia pada prasiklus, siklus I dan siklus II dapat dilihat pada Gambar 9. 


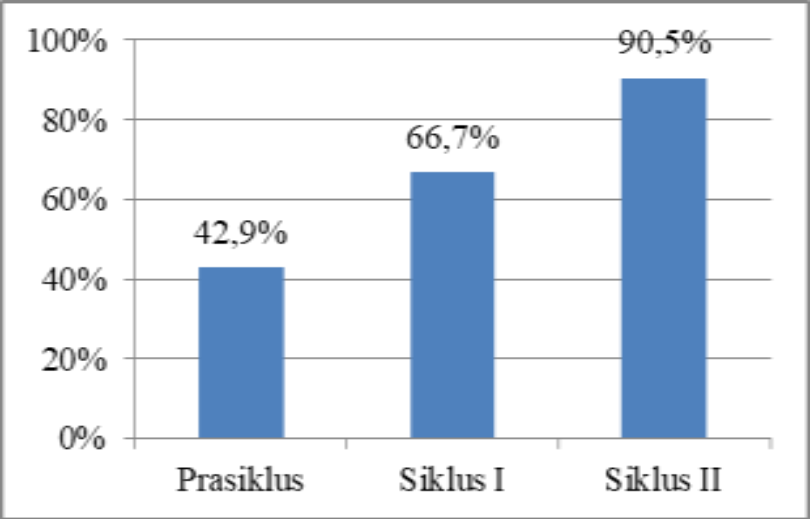

\section{Gambar 9. Diagram Ketuntasan Hasil Belajar Siswa Aspek Pengetahuan Muatan Bahasa Indonesia}

Berdasarkan Gambar 9 menunjukkan bahwa hasil belajar siswa aspek pengetahuan muatan bahasa Indonesia mengalami peningkatan ketuntasan dari prasikus, siklus I dan siklus II. Hasil belajar aspek pengetahuan muatan bahasa Indonesia dikatkan berhasil jika mencapai ketuntasan minimal 70\%. Pada prasiklus persentasenya mencapai $42.9 \%$ yang artinya terdapat 9 siswa yang tuntas dan tergolong tidak berhasil, siklus I persentasenya mencapai $66.7 \%$ yang artinya terdapat 6 siswa yang tuntas dan tergolong tidak berhasil, dan siklus II persentasenya mencapai $90.5 \%$ yang artinya terdapat 19 siswa yang tuntas dan tergolong berhasil.

\section{Hasil Belajar Siswa Aspek Keterampilan}

Hasil belajar siswa dalam penelitian ini terfokus pada keterampilan berbicara.
Berbicara adalah kemampuan mengucapkan bunyi-bunyi artikulasi atau kata-kata untuk mengekspresikan, menyatakan, atau menyampaikan pikiran, gagasan dan perasaan (Tarigan, 2008:16). Indikator observasi keterampilan berbicara sesuai pendapat Permana (2015: 134) yang sudah disesuaikan yaitu kesesuaian ucapan dengan topi, kelancaran berbicara, ketepatan pilihan kata (diksi), dan struktur kalimat. Observasi keterampilan berbicara dilakukan saat siswa mengemukakan isi video pembelajaran yang sudah diputar pada setiap pertemuan.

Hasil belajar siswa aspek keterampilan diperoleh dari observasi keterampilan berbicara siklus I dan siklus II. Hasil belajar aspek keterampilan siklus I pada Gambar 10.

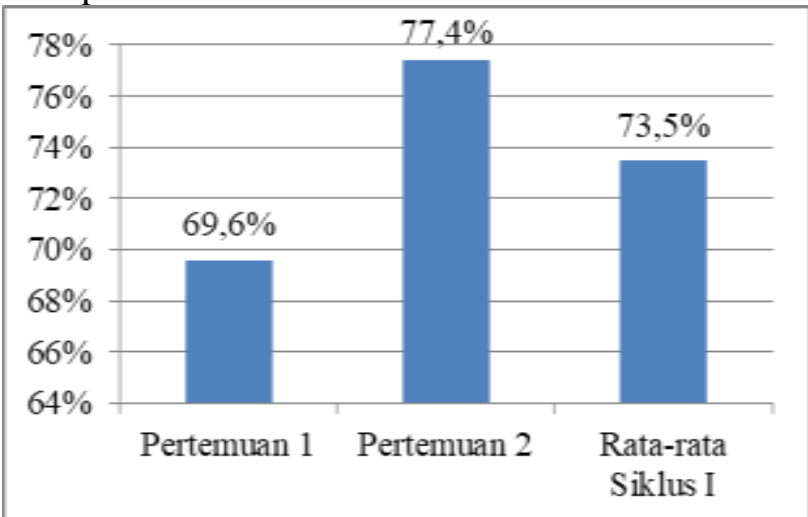

Gambar 10. Diagram Ketuntasan Hasil Belajar Aspek Keterampilan Siklus I 

keterampilan mengalami peningkatan persentase pada siklus I. Pada siklus I pertemuan I persentase nilai hasil belajar aspek keterampilan mencapai $69.6 \%$ dengan kriteria perlu bimbingan dan meningkat pada pertemuan 2 menjadi $77.4 \%$ dengan kriteria cukup. Berdasarkan kedua pertemuan pada pertemuan 1 dan 2, rata-rata siklus I mencapai 73.5\% dengan kriteria cukup.

Ketuntasan hasil belajar siswa aspek keterampilan siklus I pertemuan 1 diperoleh 11 siswa persentase ketuntasannya $52.4 \%$ kriteria perlu bimbingan, sedangkan pertemuan 2 diperoleh 16 siswa persentase ketuntasannya $76.2 \%$ dengan kriteria cukup. Berdasarkan hal tersebut, ketuntasan hasil belajar aspek keterampilan siklus I $76.2 \%$ kriteria cukup. Untuk meningkatkan hasil belajar aspek keterampilan dilakukan penelitian siklus II. Peningkatan persentase hasil belajar siswa aspek keterampilan siklus II dapat dilihat pada Gambar 11.

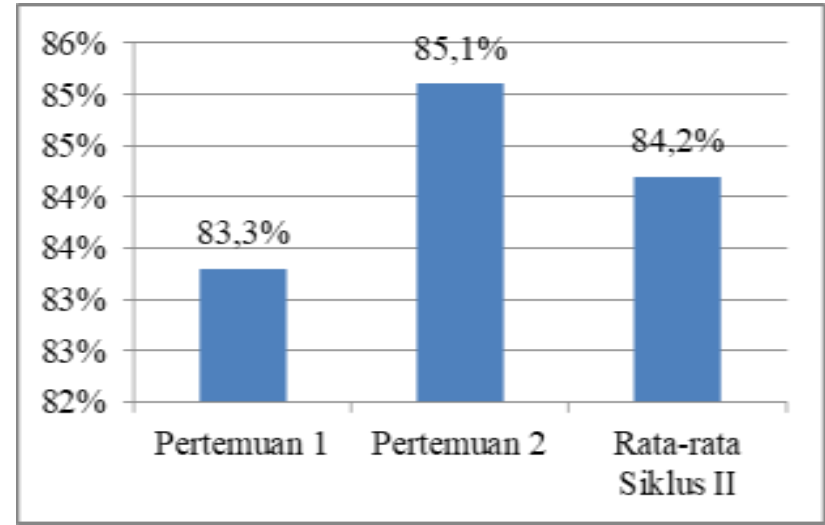

Gambar 11. Diagram Ketuntasan Hasil Belajar Aspek Keterampilan Siklus II

Berdasarkan Gambar $\quad \mathbf{1 1}$ menunjukkan bahwa hasil observasi hasil belajar aspek keterampilan mengalami peningkatan persentase pada siklus II. Pada siklus II pertemuan I persentase nilai hasil belajar aspek keterampilan mencapai $83.3 \%$ dengan kriteria baik dan meningkat pada pertemuan 2 menjadi $85.1 \%$ dengan kriteria baik. Berdasarkan kedua pertemuan pada pertemuan 1 dan 2, rata-rata siklus II mencapai $84.2 \%$ dengan kriteria baik.

Ketuntasan hasil belajar siswa aspek keterampilan siklus II pada pertemuan 1 diperoleh 16 siswa dengan persentase ketuntasannya mencapai $76.2 \%$ dengan kriteria cukup, sedangkan pada pertemuan 2 diperoleh 18 siswa dengan persentase ketuntasannya mencapai $86.7 \%$ dengan kriteria baik. Berdasarkan hal tersebut, ketuntasan hasil belajar aspek keterampilan pada siklus II adalah $86.7 \%$ dengan kriteria baik.

\section{Pembahasan}

Keterampilan guru dalam mengelola pembelajaran adalah kemampuan yang dimiliki guru dalam proses belajar mengajar melalui indikator keterampilan sebagai pedoman dalam mengelola pembelajaran. Dalam observasi keterampilan guru dalam mengelola pembelajaran ini sesuai pendapat Rusman (dalam Ardianti, Ulya dan Ismaya, 2018: 153-154) bahwa indikator keterampilan dasar mengajar yaitu keterampilan membuka pelajaran, keterampilan bertanya, keterampilan memberi penguatan, keterampilan mengadakan variasi, keterampilan menjelaskan, keterampilan membimbing diskusi kecil, keterampilan mengelola kelas, keterampilan 
pembelajaran perseorangan dan keterampilan menutup pelajaran. Berdasarkan pendapat yang dikemukakan tersebut terdapat 9 indikator, sedangkan pada penelitian ini dijabarkan lagi menjadi 25 butir observasi yang akan diamati.

$$
\text { Berdasarkan observasi muncul }
$$

permasalahan-permasalahan yang dihadapi guru. Guru kurang dalam menguasai kelas secara menyeluruh, guru hanya memperhatikan siswa yang duduknya di depan, siswa kurang bisa memotivasi siswa untuk mengikuti pembelajaran, dan kurang dalam memberikan pertanyaan menantang untuk menggali pengetahuan siswa. Penerapan model student teams achievement division (STAD) berbantun media video pembelajaran mampu menjadi solusi dalam mengatasi masalah-masalah yang dihadapi guru.

Pada siklus I persentase rata-ratanya mencapai $76 \%$ dengan kriteria baik, sedangkan pada siklus II persentase rata-ratanya mencapai $87 \%$. Berdasarkan peningkatan tiap siklusnya dapat dilihat bahwa model STAD berbantuan media video pembelajaran mampu mendorong guru untuk meningkatkan kinerjanya selama proses belajar mengajar sehingga dikatakan berhasil sesuai indikator yang diamati.

Penelitian ini sejalan dengan penelitian yang dilakukan Ari Fitri Ciptaning Aji dan Julianto berjudul "Penerapan model pembelajaran STAD untuk meningkatkan hasil belajar IPA siswa kelas IV tema Cita-citaku SDN 02 Tulungrejo Banyuwangi". Persamaan dalam peneitian ini yaitu meneliti hasil belajar siswa dan menggunakan model student teams achievement division (STAD). Hasil observasi keterampilan guru dalam penelitian yang dilakukan Ari Fitri Ciptaning Aji dan Julianto mengalami peningkatan dari $76.45 \%$ menjadi $86.9 \%$.

Hasil belajar siswa aspek pengetahuan muatan IPS dan bahasa Indonesia mengalami peningkatan. Ketuntasan muatan IPS pada prasiklus mencapai 47.6\% (Perlu Bimbingan), siklus I mencapai persentase $71.4 \%$ (Cukup), dan meningkat pada siklus II persentasenya mencapai $85.7 \%$ (Baik). Hasil belajar siswa aspek pengetahuan prasiklus muatan bahasa Indonesia mencapai 42.9\% (Perlu Bimbingan), siklus I menjadi $66.7 \%$ (Perlu Bimbingan), dan meningkat pada siklus II menjadi $90.5 \%$ (Sangat Baik). Hasil belajar aspek keterampilan pada siklus I ketuntasannya mencapai $76.2 \%$ (Cukup) dan meningkat pada siklus II persentase ketuntasannya mencapai $85.7 \%$ (Baik).

Penelitian ini sejalan dengan penelitian yang dilakukan oleh Ari Fitri Ciptaning Aji dan Julianto dengan judul penelitian "Penerapan model pembelajaran STAD untuk meningkatkan hasil belajar IPA siswa kelas IV tema Cita-citaku SDN 02 Tulungrejo Banyuwangi". Persamaan dalam peneitian ini yaitu meneliti hasil belajar siswa dan menggunakan model student teams achievement division (STAD). Hasil belajar yang dilakukan Ari Fitri Ciptaning Aji dan Julianto pada siklus I ketuntasannya mencapai $67.5 \%$ dengan rata-rata 72.97 dan meningkat pada siklus II ketuntasan klasikal mencapai $83.7 \%$ dengan rata-rata 81.08 .

$\begin{array}{lrr}\text { Berdasarkan pernyataan } & \text { tersebut } \\ \text { setelah dilakukan tindakan } & \text { dengan } \\ \text { menggunakan model student } & \text { teams }\end{array}$ achievement division (STAD) berbantuan media video pembelajaran pada tema 7 peristiwa dalam kehidupan muatan IPS dan bahasa Indonesia kelas V SD 5 Gondoharum Kudus mengalami peningkatan keterampilan guru dalam mengelola pembelajaran dan hasil belajar siswa sudah memenuhi indikator keberhasilan dengan minimal persentase $70 \%$.

\section{SIMPULAN DAN REKOMENDASI Simpulan}

Berdasarkan hasil penelitian tindakan kelas (PTK) yang dilaksanakan pada kelas V SD 5 Gondoharum Kecamatan Jekulo Kabupaten Kudus tentang "Peningkatan Hasil Belajar Tema Peristiwa dalam Kehidupan Menggunakan Model Student Teams Achievement Division berbantuan Video Siswa Kelas V SD 5 Gondoharum" mengalami peningkatan dan sesuai dengan indikator 
keberhasilan yang sudah ditentukan. Hal tersebut dibuktikan pada hasil belajar aspek pengetahuan dan keterampilan serta observasi keterampilan guru dalam mengelola pembelajaran.

Hasil observasi keterampilan guru dalam mengelola pembelajaran mengalami peningkatan persentase dari $76 \%$ (Baik dan Berhasil) pada siklus I menjadi 87\% (Sangat Baik dan Berhasil) pada siklus II.

Hasil belajar siswa aspek pengetahuan prasiklus muatan IPS ketuntasannya mencapai 47.6\% (Perlu Bimbingan), siklus I meningkat menjadi $71.4 \%$ (Cukup), sedangkan siklus II mencapai $85.7 \%$ (Baik). Hasil belajar siswa aspek pengetahuan prasiklus muatan bahasa Indonesia mencapai 42.9\% (Perlu Bimbingan), siklus I menjadi 66.7\% (Perlu Bimbingan), dan meningkat pada siklus II menjadi $90.5 \%$ (Sangat Baik). Hasil belajar siswa aspek keterampilan pada siklus I ketntasannya mencapai $76.2 \%$ (Cukup) dan meningkat pada silklus II persentase ketuntasannya mencapai $85.7 \%$ (Baik).

\section{Saran}

Berdasarkan penelitian ini, peneliti memberikan saran yaitu model pembelajaran student teams achievement division berbantuan video dapat diterapkan pada penelitian lain dengan muatan pelajaran yang berbeda.

\section{DAFTAR PUSTAKA}

Aji, A., Ciptaning, F., dan Julinto, J. (2019). Penerapan Model Pembelajaran STAD untuk Mneingkatkan Hasil Belajar IPA Siswa Kelas IV Tema Cita-citaku SDN 02 Tulungrejo Banyuwangi. JPGSD, 7 (5), 1-10.

Ardianti, S. D., Himmatul, U., Ismaya, A., \& Erik, E. (2018). Pakem dalam Kurikulum 2013. Kudus: Badan Penerbit Universitas Muria Kudus.

Arikunto, S. (2011). Penelitian Tindakan Kelas. Jakarta: Bumi Aksara.
Daryanto. (2012). Media Pembelajaran. Bandung: PT Sarana Tutorial Nurani Sejahtera.

Hamdayama, J. (2014). Model dan Metode Pembelajaran Kreatif dan Berkarakter. Bogor: Ghalia Indonesia.

Kunandar. (2013). Penilaian Autentik (Penilaian Hasil Belajar Peserta Didik Berdasarkan Kurikulum 2013). Jakarta: PT Raja Grafindo Persada.

Kurniasih, I., dan Sani, B. (2014). Implementasi Kurikulum 2013 Konsep dan Penerapan. Surabaya: Kata Pena.

Mahendra, M. (2015) Penerapan animasi Powtoon sebagai Upaya Meningkatkan Minat Belajar IPS ppada Siswa Kelas IV Sekolah Dasar Negeri Kragilan 02 Sukohardjo Tahun Pelajaran 2015/2016. Widya Sari, 18 (5), 69-74.

Mudyahardjo, R. (2010). Pengantar Pendidikan. Jakarta: PT Raja Grafindo Persada.

Mulyasa. (2013). Praktik Penelitian Tindakan Kelas. Bandung: Remaja Rosdakarya.

Permana, E. P. (2015). Pengembangan Media Pembelajaran Boneka Kaos Kaki untuk Meningkatkan Keterampilan Berbicara Siswa Kelas II Sekolah Dasar. Profesi Pendidikan Dasar, 2 (2), 133-140.

Rusman. (2012). Belajar dan Pembelajaran Berbasis Komputer. Bndung: Alfabeta.

Sapriya. (2009). Pendidikan IPS. Bandung: PT Remaja Rosdakarya Offset.

Santoso, P., dkk. (2009). Materi Pembelajaran Bahasa Indonesia SD. Jakarta: Universitas Terbuka.

Shoimin, A. (2014). 68 Model Pembelaljarn Inovatif dalam Kurikulum 2013. Yogyakarta: Ar-Ruzz Media.

Sudjana, N. (2011). Dasar-dasar Proses Belajar Mengajar. Bandung: Sinar Baru Algensindo.

Sumadoyo, S. (2013). Penelitian Tindaan Kelas. Yogyakarta: Graha Ilmu.

Susanto, A. (2013). Teori Belajar dan Pembelajaran di Sekolah Dasar. Jakarta: PT Prenamedia Group. 


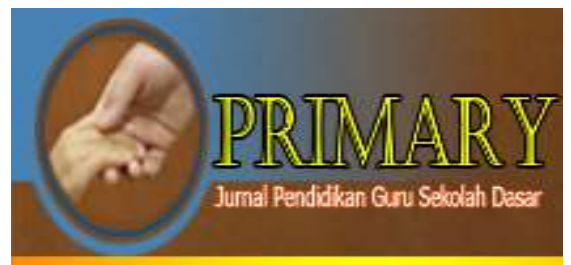
PRIMARY: JURNAL PENDIDIKAN GURU SEKOLAH DASAR
VOLUME 10 NOMOR 3 JUNI 2021
ISSN : 2303-1514 | E-ISSN : 2598-5949
DOI : http://dx.doi.org/10.33578/jpfkip.v10i3.7998
https://primary.ejournal.unri.ac.id/index.php/JPFKIP

Tarigan, H. G. (2008). Berbicara: sebagai Suatu Keterampilan Berbahasa. Bandung: Angkasa.

Uno dkk. (2014). Variabel Penelitian dalam Pendidikan dan Pembelajaran. Jakarta: PT Ina Publikatama. 